\title{
Quantitative proteomic study of human prostate cancer cells with different metastatic potentials
}

\author{
QUN LI $^{1 *}$, YILEI LI $^{2 *}$, YANYING WANG ${ }^{3 *}$, ZHENG CUI $^{4}$, LULU GONG $^{5}$, ZHIGANG QU $^{6}$,

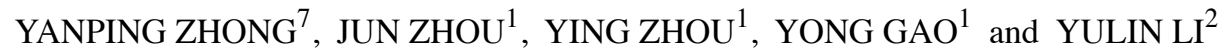

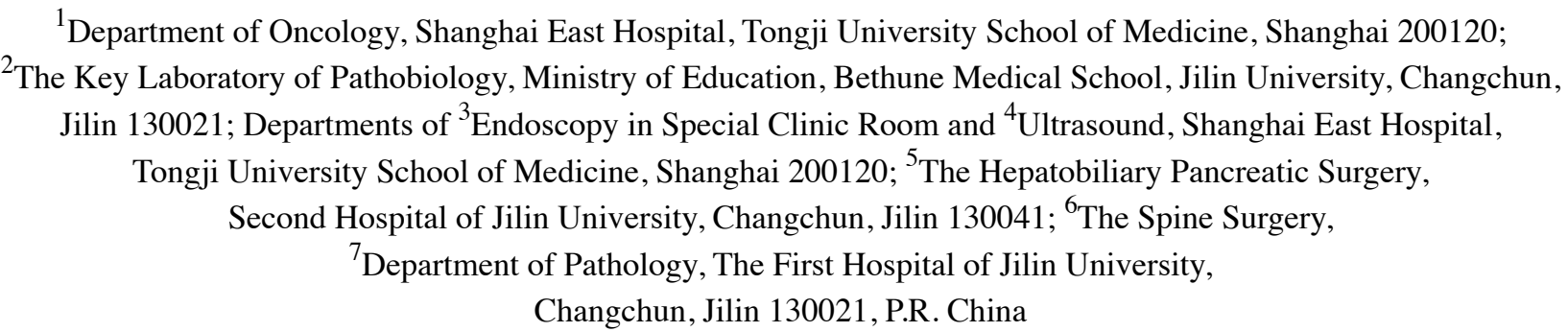

Received October 10, 2015; Accepted November 11, 2015

DOI: $10.3892 /$ ijo.2016.3378

\begin{abstract}
Metastatic dissemination is a feature of most cancers including prostate cancer $(\mathrm{PCa})$, and is the main cause of treatment failure and mortality. The aim of the study is to explore the mechanisms of PCa metastasis and to search for potential prognostic markers using proteomics. Two-dimensional fluorescent differential gel electrophoresis (2D-DIGE) was used to quantify proteins in normal prostate epithelial cells, bone
\end{abstract}

Correspondence to: Dr Yong Gao, Department of Oncology, Shanghai East Hospital, Tongji University School of Medicine, Shanghai 200120, P.R. China

E-mail: gaoyon@hotmail.com

Dr Yulin Li, The Key Laboratory of Pathobiology, Ministry of Education, Bethune Medical School, Jilin University, Changchun 130021, Jilin 130021, P.R. China

E-mail: ylli@jlu.edu.cn

${ }^{*}$ Contributed equally

Abbreviations: PCa, prostate cancer; 2D-DIGE, two-dimensional fluorescent differential gel electrophoresis; PSA, prostate-specific antigen; ATCC, American Type Culture Collection; ACN, acetonitrile; $\alpha$-HCCA, $\alpha$-cyano-4-hydroxycinnamic acid; TFA, trifluoroacetic acid; DTT, dithiothreitol; IPG, immobiline pH-gradient; PBS, phosphate-buffered saline; PI, propidium iodide; PCNA, proliferating cell nuclear antigen; IEF, isoelectric focusing; TCA, trichloroacetic acid; NCBI, National Center for Biotechnology Information; IHC, immunohistochemistry; SD, standard deviation; PMF, peptide mass fingerprint; HSP, heat shock protein; GRP, glucose-regulated protein precursor; TUBA1C, tubulin $\alpha-1 \mathrm{C}$ chain; CK-19, keratin type I cytoskeletal 19; CK-18, keratin type I cytoskeletal 18; PDIA3, protein disulfide-isomerase A3 precursor; ATPB, ATP synthase subunit $\beta$

Key words: metastasis, prognosis, prostate cancer, two-dimensional fluorescent differential gel electrophoresis, SETDB1 metastasis-derived PC-3 cells, and visceral metastasis-derived PC-3M cells. Metastatic potential was confirmed by flow cytometry, electron microscopy, proliferating cell nuclear antigen assay, and wound healing assay. Differential protein expression was compared between PCa cells with different metastatic potentials (LNcap, DU145, PC-3 and PC-3M) and normal prostate epithelial cells (RWPE-1). Selected candidate proteins in human prostate tissues were analyzed using GOA, UniProt and GeneCards analyses. Eighty-six proteins were differentially expressed between cell lines $(>1.5$-fold, $\mathrm{P}<0.05)$. Among them, twelve proteins were identified by MALDI-TOF-MS. One protein was upregulated in normal prostate epithelial cells, nine proteins were upregulated in PC-3, and two proteins were upregulated in $\mathrm{PC}-3 \mathrm{M}$. Proteins were divided into five groups according to their functions. The SETDB1 protein was closely associated with the prognosis of PCa. Bioinformatics suggested that SETDB1 might promote PCa bone metastasis through the WNT pathway. In conclusion, SETDB1 might be associated with the development of bone metastases from PCa. Further study is necessary to assess its exact role in PCa.

\section{Introduction}

Prostate cancer (PCa) is the most common malignancy in males and the second cause of cancer-related death in the USA and Europe (1). The incidence and mortality of PCa are rapidly increasing in China because of changes in diet and aging of the population (2). The proportion of PCa diagnosed at its early stage has increased because of the widespread screening of serum prostate-specific antigen (PSA) in the last two decades (3). However, many patients still present metastases at diagnosis, and metastases are the first factor leading to death from PCa (4). Patients with metastases do not benefit from radical prostatectomy or radiotherapy $(5,6)$. Therefore, novel treatment approaches are needed.

Proteomics is a powerful and effective tool to evaluate protein profiles (7). Two-dimensional fluorescent differential 
gel electrophoresis (2D-DIGE) using a mixed-sample internal standard is now recognized as an accurate method to determine and quantify differentially expressed proteins in mammals (8). The advantage of 2D-DIGE vs. 2-DE is that 2D-DIGE allows defining a statistical significance threshold for the differences in protein expression between disease and control specimens (9). To date, the 2D-DIGE-MS/MS approach has been successfully used to study different types of cancers (10). Protein and gene expression profiling studies have been performed on $\mathrm{PCa}$ specimens $(11,12)$, but these studies did not specifically explore the genes involved in the metastatic spread of PCa.

Therefore, the present study aimed to identify proteins differentially expressed between normal prostate epithelial cells and cell lines with different metastatic potential by coupling laser microdissection (LCM) with 2D-DIGE. Differentially expressed proteins were analyzed using bioinformatics including GOA, UniProt and GeneCards databases. Identifying proteins involved in PCa metastatic spread might reveal new targets for the prevention and treatment of PCa metastases.

\section{Materials and methods}

Materials and chemical reagents. The human normal prostate tissue samples were obtained from autopsies. The human normal prostate cell line RWPE-1 and the human PCa cell lines PC-3, PC-3M, LNcap clone FGC, and DU145 were obtained from the American Type Culture Collection (ATCC) (Rockville, MD, USA). F12 and IMDM culture media were from Invitrogen (Carlsbad, CA, USA). K-SFM, RPMI-1640, and MEM culture media were from Gibco (Big Island, NY, USA). Acetonitrile (ACN), hACTH (18-39), and Ang III were from Sigma (St. Louis, MO, USA). Urea, SDS, glycine, Tris, bromophenol blue, ammonium persulfate, trypsin (sequencing grade), $\alpha$-cyano-4-hydroxycinnamic acid $(\alpha$-HCCA), trifluoroacetic acid (TFA), dithiothreitol (DTT), acrylamide, methylenebisacrylamide, CHAPS, thiourea, iodoacetamide, Clean-up kit, 2D Quant kit, nuclease mix, PhastGel Blue tablets, immobiline pH-gradient (IPG) strip (pH 3.0-10.0), Pharmalyte ( $\mathrm{pH} 3.0-10.0)$, IPG buffer $(\mathrm{pH} 3.0-10.0)$, and fluorescent dyes $\mathrm{Cy} 2, \mathrm{Cy} 3$, and Cy5 were from Amersham Biosciences-GE Healthcare (Uppsala, Sweden).

Cells and culture. The PC-3 cell line was cultured in F12 medium containing $10 \%$ fetal calf serum. The PC-3M cells were cultured in IMDM medium containing $10 \%$ fetal calf serum. Both medium contained $2 \mathrm{mM}$ glutamine, $50 \mathrm{U}$ of penicillin, and $50 \mu \mathrm{g} / \mathrm{ml}$ of streptomycin. Cells were maintained at $37^{\circ} \mathrm{C}$ in a humidified atmosphere of $95 \%$ air and $5 \% \mathrm{CO}_{2}$. Adherent cells were washed three times with PBS and scraped using a sterile cell scraper. Three dishes of cells at different generations were mixed together. Cells were centrifuged at $1,000 \mathrm{xg}$ for $10 \mathrm{~min}$ at $4^{\circ} \mathrm{C}$. After removing the supernatant, the cell pellets were snap-frozen in liquid nitrogen and stored at $-80^{\circ} \mathrm{C}$. The study protocol was approved by the ethics committee of our hospital, and all participants provided written informed consent.

Cell cycle assessment. The PC-3 and PC-3M cells were digested using trypsin and collected using $0.25 \%$ pancreatic enzymes in $0.02 \%$ EDTA. Cell number was adjusted to $1 \times 10^{6}$ per sample. Cells were washed two times in phosphatebuffered saline (PBS) and fixed in $2 \mathrm{ml}$ of $70 \%$ cold ethanol. Ethanol was removed after $5 \mathrm{~min}$ by centrifugation at $4{ }^{\circ} \mathrm{C}$ and $2,000 \mathrm{rpm}$. The cells were washed once in PBS and $0.5 \mathrm{ml}$ of RNase $(5 \mu \mathrm{g} / \mathrm{ml})$ was added. Cells were incubated at $37^{\circ} \mathrm{C}$ for $30 \mathrm{~min}$. Then, DNA was stained using propidium iodide (PI) $(50 \mu \mathrm{g} / \mathrm{ml})$ in the dark for $30 \mathrm{~min}$ at $4^{\circ} \mathrm{C}$. Cell cycle analysis was performed using flow cytometry and the Cellfit software.

The S-phase fraction and the proliferation index were calculated according to:

$$
\begin{aligned}
& \mathrm{SPF}=\frac{\mathrm{S}}{\mathrm{G} 0 / \mathrm{G} 1+\mathrm{S}+\mathrm{G} 2 / \mathrm{M}} \times 100 \% \\
& \mathrm{PI}=\frac{\mathrm{S}+\mathrm{G} 2 / \mathrm{M}}{\mathrm{G} 0 / \mathrm{G} 1+\mathrm{S}} \times 100 \%
\end{aligned}
$$

Transmission electron microscopy. PC-3 and PC-3M cells were digested and collected using $0.25 \%$ pancreatic enzymes in $0.02 \%$ EDTA. The density of the cells was $10^{6}-10^{7} / \mathrm{ml}$. Cells were centrifuged $5 \mathrm{~min}$ at $12,000 \mathrm{rpm}$, washed three times in PBS, and centrifuged for $10 \mathrm{~min}$ at $1,500 \mathrm{rpm}$. Cells were fixed using $4 \%$ glutaric dialdehyde and $1 \%$ perosmic acid, and were dehydrated in ethanol series. Cells were embedded in Epon 812 epoxy resin and sliced into ultrathin sections, which were stained using uranyl acetate and lead citrate. Finally, cells were observed using a JEM-1200EX transmission electron microscope (Jeol, Tokyo, Japan).

Proliferating cell nuclear antigen. Cells were harvested. Peroxidase activity was blocked using $3 \% \mathrm{H}_{2} \mathrm{O}_{2}$ at room temperature for 15 min. Cells were washed in PBS (pH 7.4) three times, 5 min each time. Non-immunologic animal serum was added, and the cells were incubated for $30 \mathrm{~min}$ at room temperature. Serum was discarded, and anti-mouse proliferating cell nuclear antigen (PCNA) monoclonal antibody (1:500) was added and incubated overnight at $4^{\circ} \mathrm{C}$. Cells were washed in PBS three times, 5 min each time. The secondary antibody was added and incubated for $20 \mathrm{~min}$ at room temperature. Cells were washed in PBS three times, 5 min each time. Horseradish peroxidase-conjugated antibodies were added and incubated for $20 \mathrm{~min}$ at room temperature. Cells were washed in PBS three times, 5 min each time. The DAB solution was added. Cells were observed after 3-10 min using a light microscope. Cells were washed using tap water, and counterstained using hematoxylin, dehydrated using an ethanol series, treated with xylene, and sealed with neutral resin. Negative control was obtained by replacing the first antibody by PBS.

Migration assay. Cells $\left(1 \times 10^{4}\right)$ were seeded onto a Matrigelprecoated 24-well plate and cultured to $95 \%$ confluence. A wound was created on the cell monolayers using a $10-\mu 1$ micropipette tip and photographed at a magnification of $\mathrm{x} 100$. Monolayer cells with wounds were cultured in serum-free medium for $12 \mathrm{~h}$ and then photographed at the same position. The width of each cell wound was calculated using the ImageJ software program (National Institutes of Health, Bethesda, MD, USA). The relative cell migration distance was calculated using the following formula: relative migration distance (\%) 
$=100(\mathrm{~A}-\mathrm{B}) / \mathrm{A}$, in which $\mathrm{A}$ is the cell-wound width before incubation and $\mathrm{B}$ is the width after incubation.

Protein extraction and quantification. Cells were collected and washed twice with ice-cold PBS. Lysis buffer (7 M urea, $2 \mathrm{M}$ thiourea, 4\% CHAPS, $30 \mathrm{mM}$ Tris, $\mathrm{pH}$ 8.8) containing $1 \%$ protease inhibitors and nuclease mix was added. After pelleting the insoluble material by centrifugation at $25,000 \mathrm{x} \mathrm{g}$ for $30 \mathrm{~min}$, the supernatants were collected. According to the manufacturer's instructions, the protein samples were cleaned and quantified using the Clean-up and 2D Quant kits. Extracted proteins were stored at $-20^{\circ} \mathrm{C}$.

$2 D-D I G E$. According to the manufacturer's protocols, $50 \mu \mathrm{g}$ of protein from each sample was minimally labeled with fluorescent dyes. After incubation on ice for $30 \mathrm{~min}$, the reaction was terminated by adding $1 \mu \mathrm{l}$ of $10 \mathrm{mM}$ lysine. Cy3-, Cy5-, and Cy2-labeled samples and internal standards were pooled and the rehydration buffer (8 M urea, 2\% CHAPS, 0.4\% IPG buffer and $0.28 \%$ DTT) was added to obtain equal volumes. The samples were loaded on an IPG strip (24 cm, pH 3.0-10.0, linear) for isoelectric focusing (IEF) on an IPGphor (Amersham Biosciences-GE Healthcare) at $20^{\circ} \mathrm{C}$ and $30 \mathrm{~V}$ for $12 \mathrm{~h}$ (rehydration), $500 \mathrm{~V}$ for $3 \mathrm{~h}$, grad $1,000 \mathrm{~V}$ for $1 \mathrm{~h}, \operatorname{grad} 8,000 \mathrm{~V}$ for $1 \mathrm{~h}$, and $8,000 \mathrm{~V}$ for $3 \mathrm{~h}$. After IEF, the strips were first equilibrated in an equilibration solution containing $50 \mathrm{mM}$ Tris- $\mathrm{HCl}$ (pH 8.8), $6 \mathrm{M}$ urea, 30\% (v/v) glycerol, $2 \%$ (w/v) SDS and 1\% $(\mathrm{w} / \mathrm{v})$ DTT for $15 \mathrm{~min}$, and later in the same solution except that DTT was replaced by $4 \%$ (w/v) iodoacetamide for another $15 \mathrm{~min}$. Then the IPG strips were loaded on $12.5 \%$ polyacrylamide gels using the Ettan DALT Six system (Amersham Biosciences-GE Healthcare) for electrophoresis at $1.5 \mathrm{~W} / \mathrm{gel}$ overnight until the bromophenol blue front reached the bottom of the gels. Comparisons of protein expression in 2D images were performed with DeCyder software (GE Healthcare, Waukesha, WI, USA). The pixel volume of each spot was calculated, normalized and compared between groups. Each gel was matched with the internal standard to achieve minimal gel-gel variance. A cut-off value of a 1.5-fold was used.

Image analysis. Fluorescent images were collected using a Typhoon 9400 scanner (Amersham Biosciences-GE Healthcare) at a resolution of $100 \mu \mathrm{m}$. Matching, quantification, and statistics were carried out using DeCyder Differential In Gel Analysis software (Amersham Biosciences-GE Healthcare). Images were checked manually to eliminate artifacts. Then, gels were fixed in $20 \%$ trichloroacetic acid (TCA) overnight in stained with PhastGel Blue. Another three preparative gels of normal, PC-3 and PC-3M cells were made with $450 \mu \mathrm{g}$ of protein and the same conditions. Spots of interest were excised from the DIGE analytic gels and preparative gels with the help of an Ettan Picker (Amersham Biosciences-GE Healthcare) for further identification.

Protein identification by $M S / M S$. Gel pieces were digested with trypsin in an Ettan Digester (Amersham Biosciences-GE Healthcare). First, they were destained with $50 \mathrm{mM} \mathrm{NH}_{4} \mathrm{HCO}_{3}$ in $50 \%$ methanol and then dehydrated with 50\% ACN-0.1\% TFA. After the gel pieces had dried completely, trypsin $(20 \mathrm{ng} / \mu \mathrm{l}$ in $20 \mathrm{mM} \mathrm{NH}_{4} \mathrm{HCO}_{3}$ ) was added and the samples were digested at room temperature overnight. The extracted peptides were removed, dried and resuspended in 50\% ACN-0.1\% TFA. Equal volumes of sample and $\alpha$-HCCA were spotted and mixed on the MALDI-TOF MS target slides using an Ettan Spotter (Amersham Biosciences-GE Healthcare). Peptide extracts were analyzed on a MALDI-TOF MS (Amersham Biosciences-GE Healthcare) using the positive ion reflectron mode. The accelerating potential was $20 \mathrm{kV}$ with eight shots per second. Trypsin autodigestion peaks were used as internal calibration and hACTH (19-39) and Ang III as external standards. Peptide mass data were searched against the National Center for Biotechnology Information (NCBI) database using the ProFound search engine (13) with the rat as the searched species. The basic requirement for identification was that the expectation value (chance of misidentification) was $<0.05$ and the coverage (the ratio of the protein sequence covered by the matched peptides) was $>20 \%$. The results were further confirmed in the Swiss-Prot protein database (us.expasy.org/sprot).

Functional classification of the identified proteins. The functional classification of the proteins was performed using GOA (http://www.ebi.ac.uk/goa) based on the protein accession numbers in IPI.

Immunoblotting. Proteins $(20 \mu \mathrm{g})$ from PC-3, PC-3M, brain metastasis-derived PCa DU-145, lymph node metastasisderived PCa LNcap, and normal human prostate RWPE-1 cell lines were analyzed by western blotting. After SDS-PAGE, proteins were electrotransferred to polyvinylidene fluoride membranes (Immobilon-P; Millipore, Bedford, MA, USA). The membranes were blocked for $1 \mathrm{~h}$ at room temperature in $5 \%$ non-fat dry milk in Tris-buffered saline and Tween-20, $\mathrm{pH} 7.5$ (100 mM NaCl, $50 \mathrm{mM}$ Tris, 0.1\% Tween-20), and washed in Tris-buffered saline and Tween-20. Membranes were immunoblotted with: goat polyclonal anti-GRP78 (Santa Cruz Biotechnology, Santa Cruz, CA, USA), rabbit polyclonal antiHSPA8 (Abgent Biotechnology, San Diego, CA, USA), rabbit polyclonal anti-TUBA1C (Abgent), goat polyclonal anti-HSP60 (Santa Cruz), rabbit polyclonal anti-PDIA3 (Abgent), rabbit polyclonal anti-desmin (Santa Cruz), mouse monoclonal anticytokeratin 18 (Santa Cruz), goat polyclonal anti-GRP 75 (Santa Cruz), mouse monoclonal anti-SETDB1/SETDB1 (Abcam Plc., Cambridge, UK) and glyceraldehyde-3-phosphate dehydrogenase (Santa Cruz). Primary antibodies were incubated at $4^{\circ} \mathrm{C}$ overnight, and secondary antibodies conjugated to horseradish peroxidase were incubated for $1 \mathrm{~h}$ at room temperature. The proteins were detected using an enhanced chemiluminescence detection system (Pierce, Rockford, IL, USA).

Immunohistochemistry. The UltraSensitive ${ }^{\mathrm{TM}} \mathrm{S}-\mathrm{P}$ immunohistochemistry (IHC) method was used to detect the expression of SETDB1 in $\mathrm{PCa}$, prostate tissues bordering $\mathrm{PCa}$, and bone metastases. Tissue microarrays were purchased from Xi'an Ailina Biotechnology Co., Ltd. (China). Antibody (SETDB1) was purchased from Abcam Plc. The hypersensitive UltraSensitive ${ }^{\mathrm{TM}}$ SP kit (rat/rabbit) was purchased from Maixin Biotechnology Co., Ltd. Samples were heated at $60^{\circ} \mathrm{C}$ for $30 \mathrm{~min}$, dewaxed and hydrated. Antigen retrieval was performed in a $0.01 \mathrm{M}$ citrate buffer ( $\mathrm{pH}$ 6.0) for $2 \mathrm{~min}$, cooled to room temperature, and washed with phosphate-buffered saline (PBS) $5 \mathrm{~min}$, three times. Endogenous peroxidase 
Table I. MALDI-TOF results of twelve differentially expressed proteins in prostate cancer.

\begin{tabular}{lclcccl}
\hline Spot no. & Expectation $^{\text {a }}$ & Accession no. & Cover Percent $^{\mathrm{b}}$ & MW & PI & Name \\
\hline 1,144 & 0.000 & gi 1143492 & $26.2 \%$ & 72.210 & 5.0 & 78 kDa glucose-regulated protein precusor \\
1,480 & 0.001 & gi 4204880 & $23.9 \%$ & 70.260 & 5.6 & Heat shock cognate 71 kDa protein \\
1,397 & 0.000 & gi 340021 & $29.3 \%$ & 49.895 & 4.9 & Tubulin $\alpha$-1C chain \\
1,400 & 0.000 & gi 7702086 & $20.3 \%$ & 61.360 & 5.7 & 60 kDa heat shock protein \\
1,457 & 0.001 & gi11024686 & $20.3 \%$ & 56.782 & 6.4 & Protein disulfide-isomerase A3 precursor \\
1,560 & 0.001 & gi 860986 & $30.5 \%$ & 57.160 & 5.9 & Protein disulfide-isomerase A3 precursor \\
1,768 & 0.000 & gi 179279 & $28.4 \%$ & 56.880 & 5.4 & ATP synthase subunit $\beta$ \\
1,573 & 0.000 & gi19698555 & $26 \%$ & 53.56 & 5.2 & Desmin \\
1,765 & 0.000 & gi 32653819 & $30.5 \%$ & 48.010 & 5.4 & Keratin, type I cytoskeletal 18 \\
2,088 & 0.000 & gi 34039 & $28.7 \%$ & 44.090 & 5.0 & Keratin, type I cytoskeletal 19 \\
1,242 & 0.000 & gi 292059 & $26.1 \%$ & 74.050 & 6.0 & Stress-70 protein \\
2,288 & 0.000 & gi 1592734 & $29.3 \%$ & 9.990 & 5.6 & Histone-lysine N-methyltransferase SETDB1
\end{tabular}

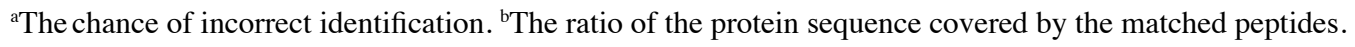

was blocked with $3 \% \mathrm{H}_{2} \mathrm{O}_{2}$ at room temperature for $10 \mathrm{~min}$. Sections were washed with PBS for 5 min, three times. Normal non-immune sera was added at room temperature for $10 \mathrm{~min}$ and then discarded. The anti-SETDB1 antibody (1:200) was added and incubated at $4^{\circ} \mathrm{C}$ overnight. Sections were washed with $0.1 \%$ Tween-20 PBS for $5 \mathrm{~min}$, three times. Sections were incubated for $10 \mathrm{~min}$ at room temperature in Streptomyces avidin-peroxidase. DAB was added for $5 \mathrm{~min}$, and washed with distilled water. Samples were counterstained with hematoxylin. Samples were dehydrated and mounted in neutral resin. Sections were examined by light microscopy. No color was negative (-), light brown was weakly positive (+), brown was positive $(++)$, and tan was strongly positive $(+++)$. The number of positive cells were $<25 \%(+)$, between 25 and $49 \%(++)$ and $>50 \%(+++)$. Sections were examined in $\geq 5-10$ random fields.

Bioinformatics and network analysis of the SETDB1 protein. The function, subcellular location, domain, biological process, and pathway of the SETDB1 protein were analyzed using the UniProt (http://www.uniprot.org) and the GeneCards (http://www.genecards.org) databases. Functional network analysis of SETDB1 was performed using STRING (14) (version 9.0; http://string.embl.de) with the following analysis parameters: species Homo sapiens, confidence level of 0.400 , and active prediction methods.

Statistical analysis. Data are expressed as means \pm standard deviation (SD). Comparison between groups was performed using univariate analysis of variance with the Tukey's post hoc test. Statistical analysis was performed using GraphPad 5.0 (GraphPad software Inc., San Diego, CA, USA). P-values $<0.05$ were considered statistically significant.

\section{Results}

PC-3M cells have higher metastatic potential compare with $P C-3$ cells. The number of PC-3M cells in S phase was significantly higher compared with PC-3 cells. The S-phase fraction and the proliferation index were also significantly higher than the control group.

PC-3 cells were observed using transmission electron microscopy. PC-3 cells had a rich rough endoplasmic reticulum, glycogen particles, and sparse microtubule microfilaments. The PC-3M cells had abundant microvilli, rich cytoplasmic mitochondria, and their microtubules microfilaments were reduced and deficient.

PCNA IHC revealed that the PCNA expression in PC-3M cells was significantly higher than in $\mathrm{PC}-3$ cells $(\mathrm{P}<0.01, \mathrm{n}=5)$. The wound healing assay showed that the relative migration distance of the PC-3M cells was $50 \pm 8$ compared with $33 \pm 5 \%$ for PC-3 cells.

2-DE protein maps of $\mathrm{PC}$ a cells. Fig. 1A-C is representative of 2D fluorescent gel images of normal prostate epithelial cells, PC-3 cells, and PC-3M cells, respectively. Among the proteins detected, 86 were changed by $>1.5$-fold. Of these 86 proteins, 12 were identified successfully by MALDI-TOF-MS (Fig. 1D). Spot 1,457 was identified as protein disulfide-isomerase A3 precursor, and was upregulated.

Protein identification and functional classification. Of the 86 differentially expressed proteins, 12 were identified by MALDI-TOF MS. Among these, one protein was upregulated in normal prostate epithelial cells, nine proteins were upregulated in PC-3 cells, and two proteins were upregulated in PC-3M cells. Table I shows their detailed information including expectation (the probability of misidentification based on mass spectral data alone), NCBI accession numbers, and coverage (the ratio of the protein sequence covered by the matched peptides). Fig. 2A presents a typical MALDI-TOF MS peptide mass fingerprint (PMF) spectrum of trypsin-digested spot 1,457, later identified as protein disulfide-isomerase A3 precursor. In some cases, one protein was identified in several discrete spots, presumably representing protein posttranslational modifications. However, the specific nature of these modifications could not be ascertained from the present 


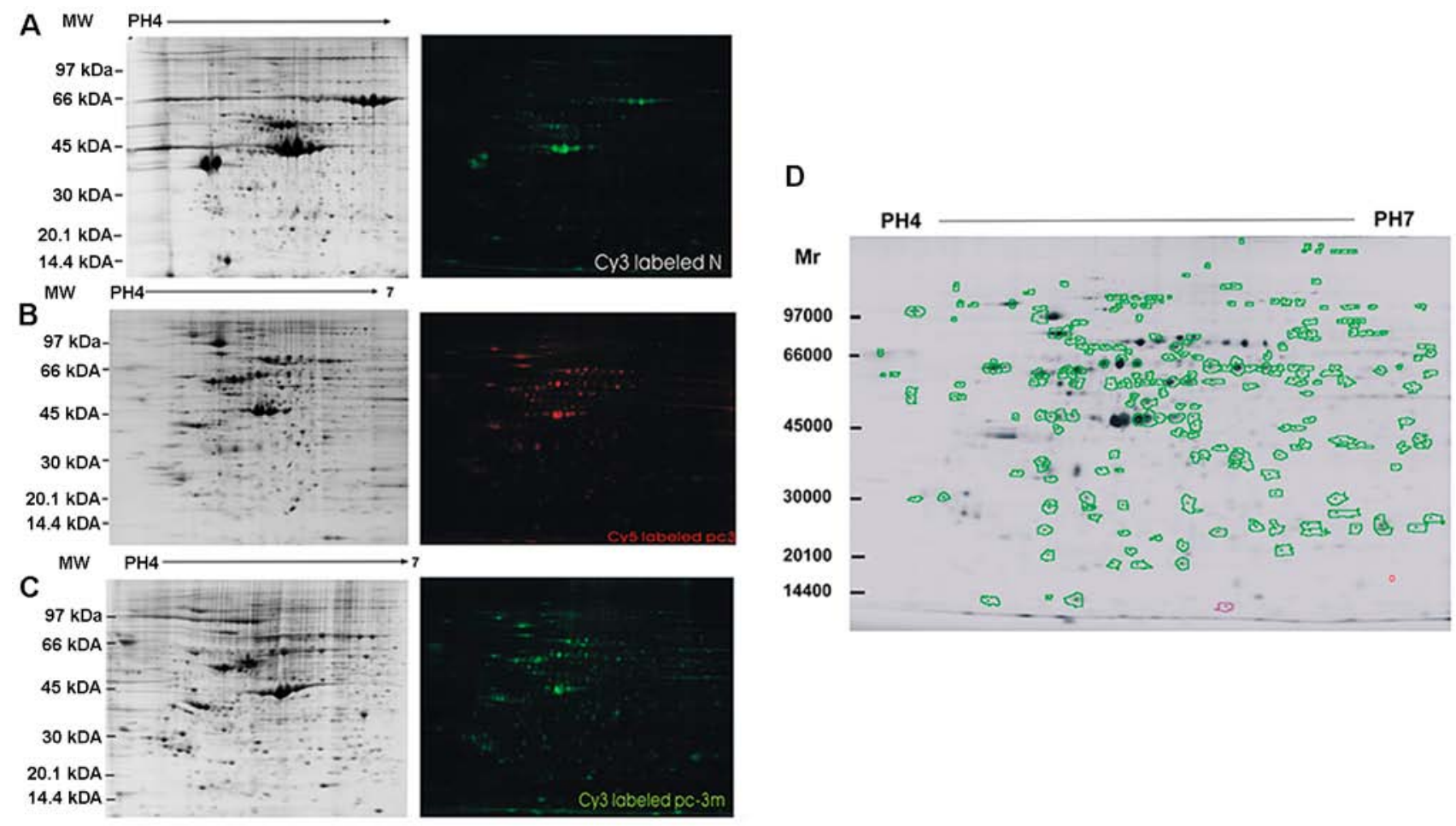

Figure 1. 2D-DIGE images of proteins from different cell lines. (A) 2D-DIGE images and fluorescence of human normal prostate cells. (B) 2D-DIGE images and fluorescence of PC-3 cells. (C) 2D-DIGE images and fluorescence of PC-3M cells. (D) Fluorescence-labeled proteins were separated on 24x20-cm gels. Protein expressions were compared using DeCyder-BVA software. Eighty-six proteins were differentially expressed, which are labeled in green on the image. Twelve of these proteins were identified by MS.

A

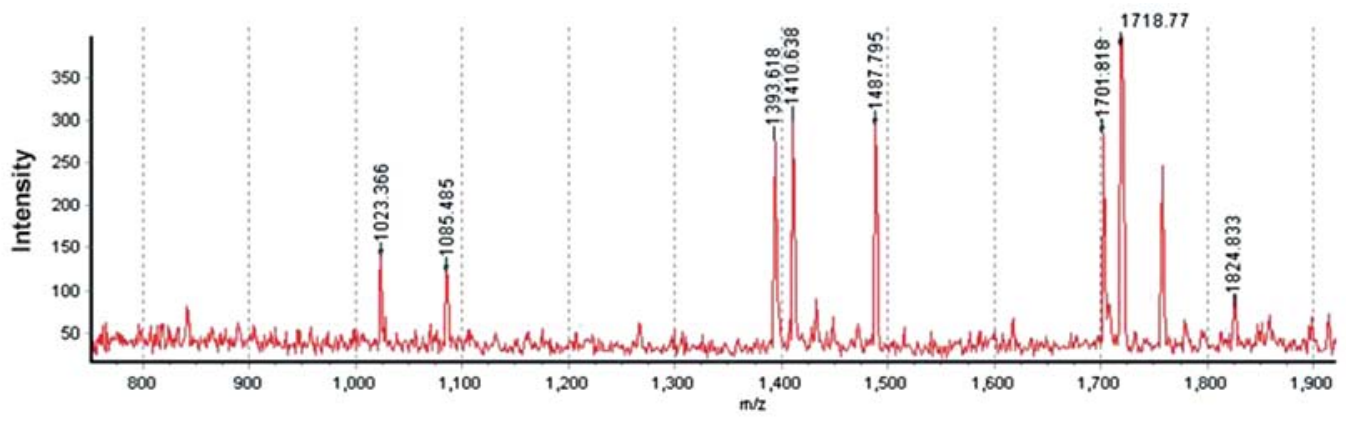

\section{Probability based Mowse score}

Protein score is $-10^{*} \log (P)$, where $P$ is the probability that the observed match is a random event. Protein scores greater than 55 are significant $(p<0.05)$.

B

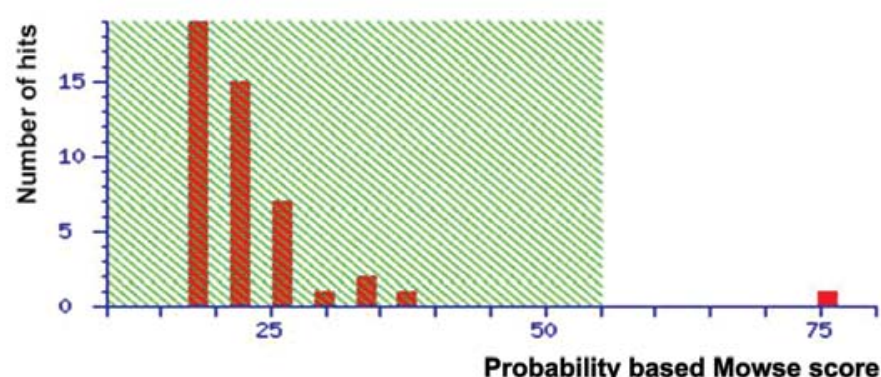

Figure 2. Typical MALDI-TOF MS PMF spectrum of trypsin-digested spot 1,457, and its Swiss-Prot database results. (A) The peptide mass fingerprinting of protein disulfide-isomerase A3 precursor. Coverage is $20.3 \%$. Expectation is 0.001 . The $\mathrm{x}$-axis represents the mass-to-charge ratio ( $\mathrm{m} / \mathrm{z}$ ), and the $\mathrm{y}$-axis represents the relative abundance. The peptide masses are labeled and annotated with their corresponding $\mathrm{m} / \mathrm{z}$. After calibration, the mass fingerprint spectrum data matched to human protein disulfide-isomerase A3 precursor, whose theoretical $\mathrm{pI}$ is 6.4 and molecular weight is 56.782 with the expectation value 0.001 ( $0.0 \%$ chance of an incorrect identification) and the protein sequence coverage was 20.3\%. (B) PMF data of protein spot 1,457 were entered in the Swiss-Prot database. Results showed that it is the protein disulfide-isomerase A3 precursor. These results were consistent with the NCBI database search result. 

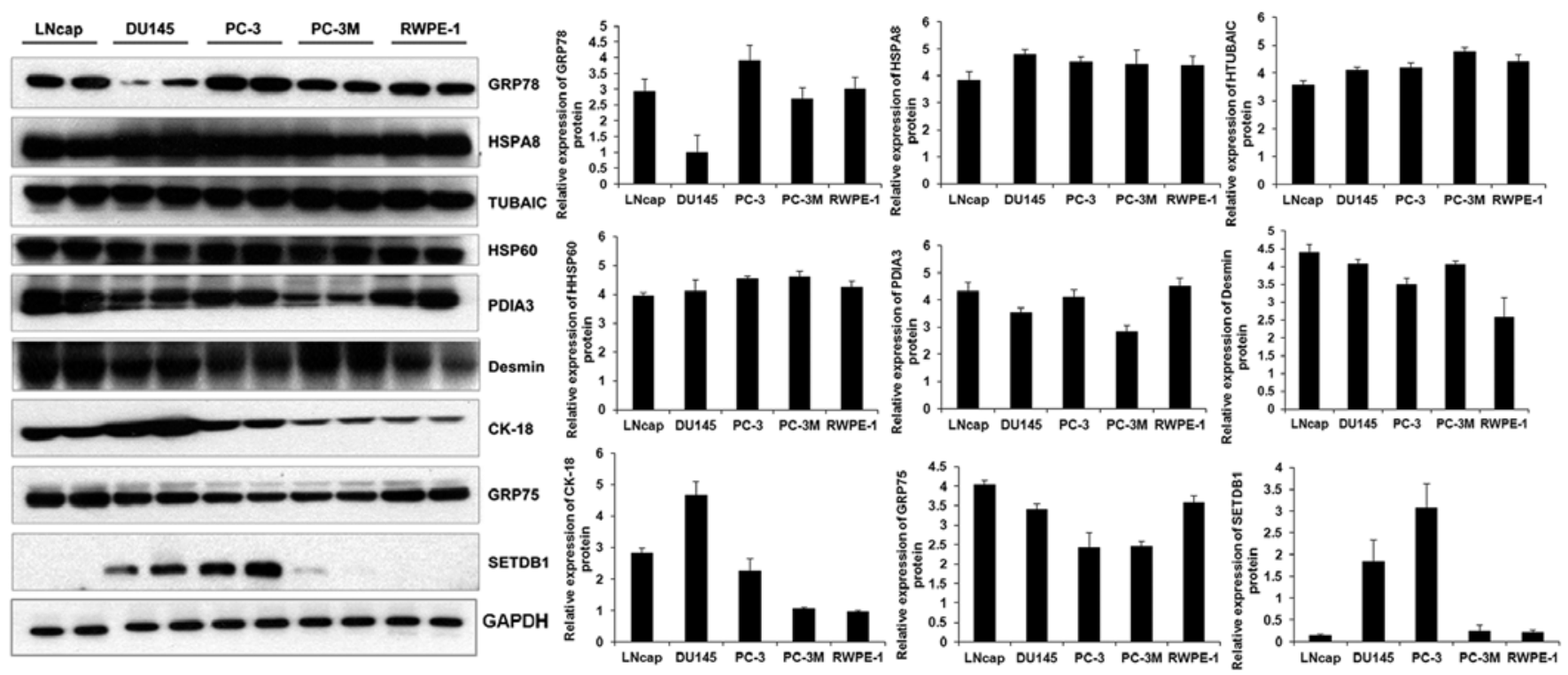

Figure 3. Differential expression of GRP78, HSPA8, TUBA1C, HSP60, PDIA3, desmin, CK-18, GRP75 and SETDB1 protein expression in human normal prostate epithelial (RWPE-1), PC-3, PC-3M, LNcap and DU-145 cells. Proteins were detected by immunobloting. PDIA3 protein was highly expressed in PC-3 cells and normal prostate cells. CK-18 protein expression was higher in PC-3 cells than in PC-3M cells and normal cells. SETDB1 expression was significantly higher in PC-3 cells, although it was also expressed in DU-145, but is was hardly expressed in normal cells, LNcap cells and PC-3M cells.

data. In the present study, scores $>55$ were considered credible $(\mathrm{P}<0.05)$. The score of the protein disulfide-isomerase A3 precursor was 76 (Fig. 2B).

The identified proteins were divided into the following five groups according to their functions. i) Binding proteins: histone-lysine N-methyltransferase SETDB1 (SETDB1), heat shock $71 \mathrm{kDa}$ protein (HSPA8), and $60 \mathrm{kDa}$ heat shock protein (HSP60). ii) Apoptosis-related proteins: $78 \mathrm{kDa}$ glucoseregulated protein precursor (GRP78), tubulin $\alpha-1 \mathrm{C}$ chain (TUBA1C), stress-70 protein (GRP75), and mitochondrial precursor. iii) Cytoskeletal proteins: desmin, keratin type I cytoskeletal 19 (CK-19), and keratin type I cytoskeletal 18 (CK-18). iv) Proteins with phospholipase c activity: protein disulfide-isomerase A3 precursor (PDIA3) and protein disulfide isomerase A3 precursor. v) Protein with transporter activity: ATP synthase subunit $\beta$ (ATPB).

Differential expression of proteins in normal prostate epithelial cells, PCa cells, and PCa tissues. GRP78, HSPA8, TUBA1C, HSP60, PDIA3, desmin, CK-18, GRP75, and SETDB1 were detected in human normal prostate epithelial cells and in PC-3, PC-3M, LNcap, and DU-145 cells by western blotting (Fig. 3). PDIA3 expression was consistent with the proteomic results in PC-3 and PC-3M cells, but was also highly expressed in normal cells; therefore, it was not a candidate protein for metastatic spread. The proteomics and western blot expression of CK-18 were consistent, it was highly expressed in PC-3 cells compared with PC-3M cells and normal cells. Whereas, SETDB1 was highly expressed in PC-3 and DU-145 cells, but it was hardly expressed in normal, LNcap, and PC-3M cells. Therefore, SETDB1 was considered as an important candidate protein for metastasis.

Subsequently, human prostate tissue chips were used to test the expression of SETDB1. The expression of SETDB1 in the PCa and bone metastases combo chip (PR956b) suggested that
SETDB1 protein was expressed in the cytoplasm and nucleus of PCa. Its expression was closely correlated with Gleason grade, and with TNM staging (Fig. 4A). Irrespective of the TNM stage, in Gleason grade I, SETDB1 protein in PCa was weakly positive (+); in Gleason grade II, SETDB1 was strongly positive $(++/+++)$; and in Gleason grade III, SETDB1 was more strongly positive (+++).

At the same time, SETDB1 protein was negative (-) in fibers, blood vessels, fat, smooth muscles, and bones. SETDB1 protein was weakly positive (+) in normal prostate and abdominal metastatic prostate cancer. SETDB1 was positive $(++)$ in PCa bone metastasis tissue (Fig. 4B).

SETDB1 analysis by bioinformatics. SETDB1 is a member of the histone-lysine methyltransferase family, Suvar 3-9 subfamily. The protein contains two Tudor domains, one MBD (methyl-CpG-binding) domain, one pre-SET domain, one SET domain, and one post-SET domain. The pre-SET, SET, and post-SET domains are all required for the methyltransferase activity. A 347-amino acid insertion in the SET domain has no effect on the catalytic activity. In the pre-SET domain, Cys residues bind three zinc ions that are arranged in a triangular cluster. Some of these Cys residues contribute to the binding of two zinc ions within the cluster.

The biological process of the SETDB1 protein includes the following (from the UniProt database): bone development (Fig. 5A), inner cell mass cell proliferation (Fig. 5B), transcription, DNA-template, histone $\mathrm{H} 3-\mathrm{K} 9$ trimethylation, and negative regulation of transcription from RNA polymerase II promoter. Data from the Gene Cards database (http://www. genecards.org) revealed that the SETDB1 protein participates in three classical pathways: chromatin regulation/acetylation, non-canonical Wnt signaling pathway, and lysine degradation.

Furthermore, single protein analysis using String 9.0 software indicated that SETDB1 interacts with MBD1, which 
A

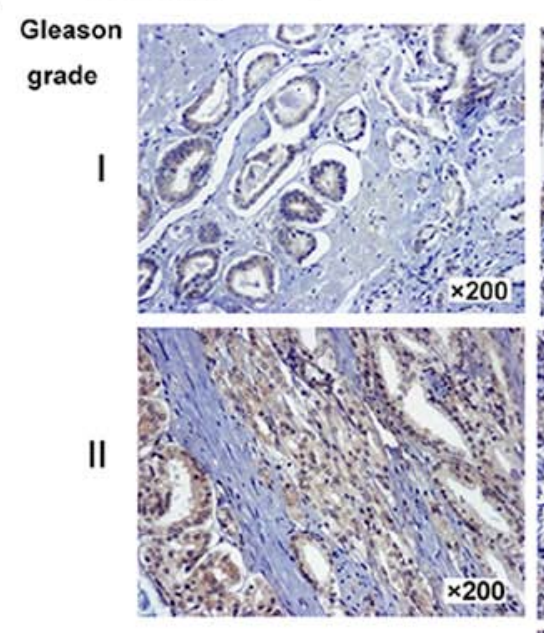

III
III
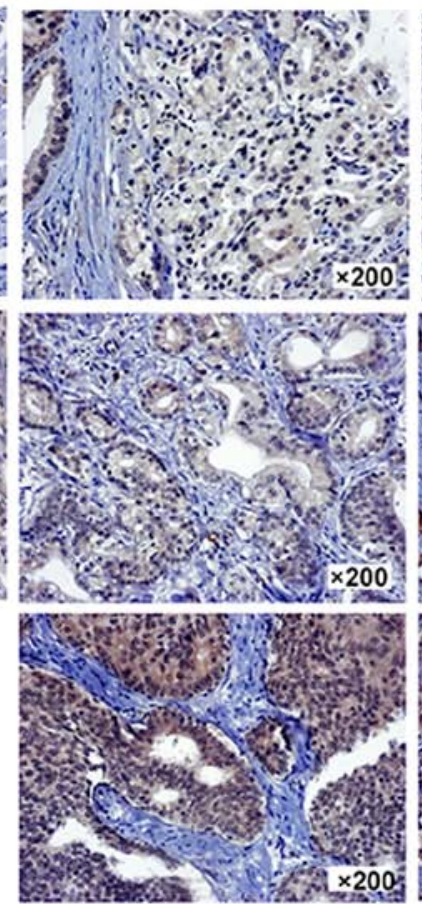

IV
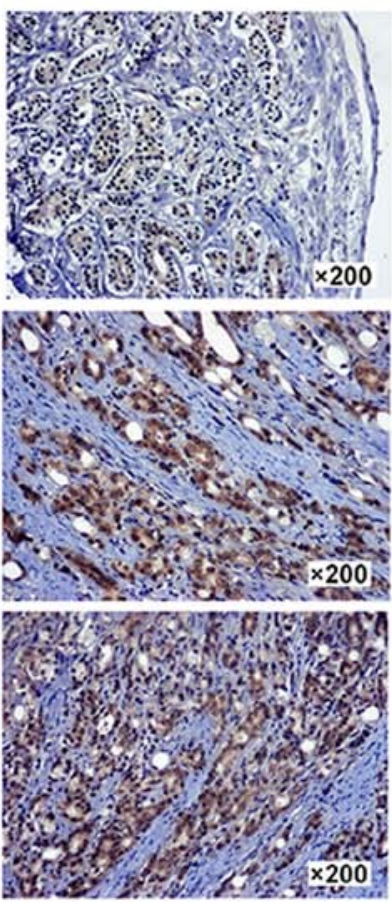

$(+)$

$(+++++)$

$(+++)$

\section{B}

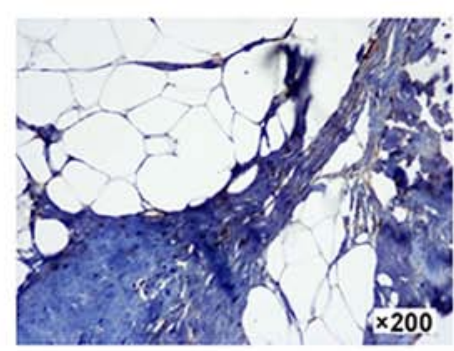

Fibers, blood vessels, fat (-)

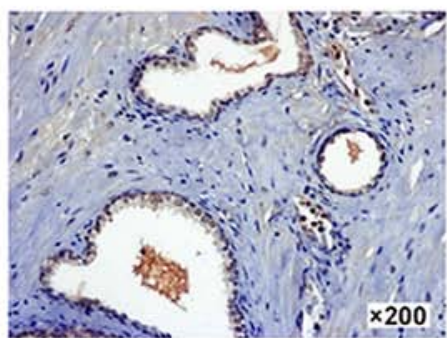

Normal prostate tissue(+)

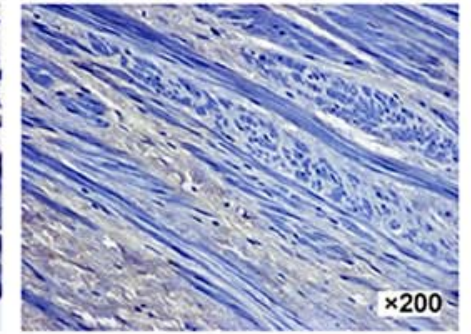

Fibers, smooth muscle (-)

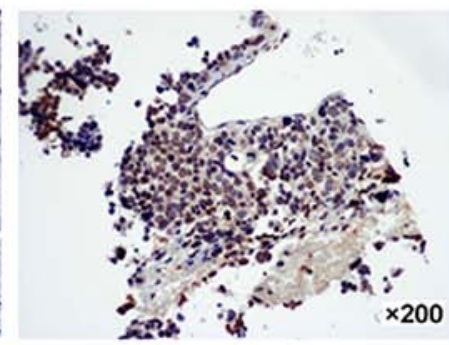

Abdominal metastasis of $\mathrm{PCa}(+)$

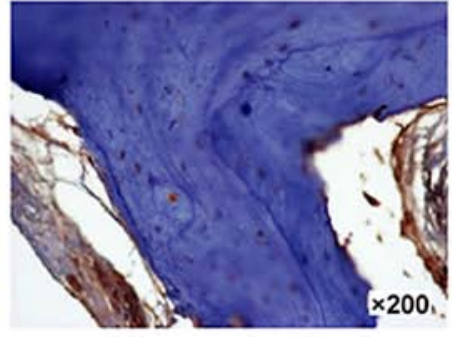

Bone tissue (-)

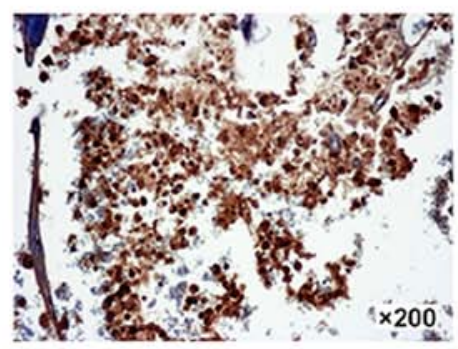

Bone metastasis of $\mathrm{PCa}(++)$

Figure 4. Detection of SETDB1 protein expression by immunohistochemistry. (A) Irrespective of the TNM stage, the higher the Gleason grade, the stronger SETDB1 protein expression level in the cytoplasm or nucleus of PCa tissue (x200). (B) SETDB1 IHC was negative in fibers, blood vessels, fat, smooth muscle and bone tissue. SETDB1 protein was weakly positive (+) in normal prostate tissue and abdominal metastatic prostate cancer tissues. It was positive in prostate cancer bone metastasis tissue.

is abolished when MBD1 is sumoylated. SETDB1 interacts with ATF7IP and ATF7IP2; the interaction with ATF7IP is required to stimulate histone methyltransferase activity and facilitate the conversion of dimethylated to trimethylated $\mathrm{H} 3$ 'Lys-9'. During DNA replication, it is recruited by SETDB1 to form an $S$ phase-specific complex that facilitates methylation of H3 Lys-9 during replication-coupled chromatin assembly and is at least composed of the CAF-1 subunit CHAF1A, MBD1, and SETDB1. SETDB1 interacts with ERG, TRIM28/TIF1B, CBX1, CBX5, CHD7, DNMT3A, HDAC1, HDAC2, NLK, PPARG, SIN3A, SIN3B, DNMT3B, and SUMO2. SETDB1 interacts with MPHOSPH8, and form part of a complex containing at least CDYL, REST, WIZ, SETB1, EHMT1, and EHMT2 (Fig. 6). 
A

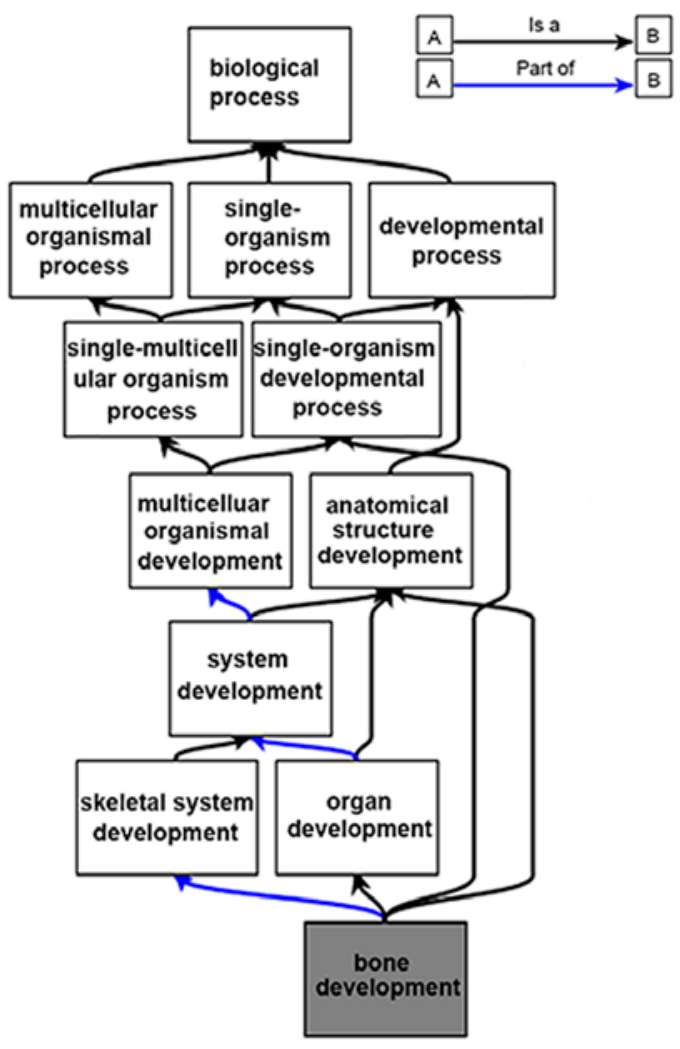

B
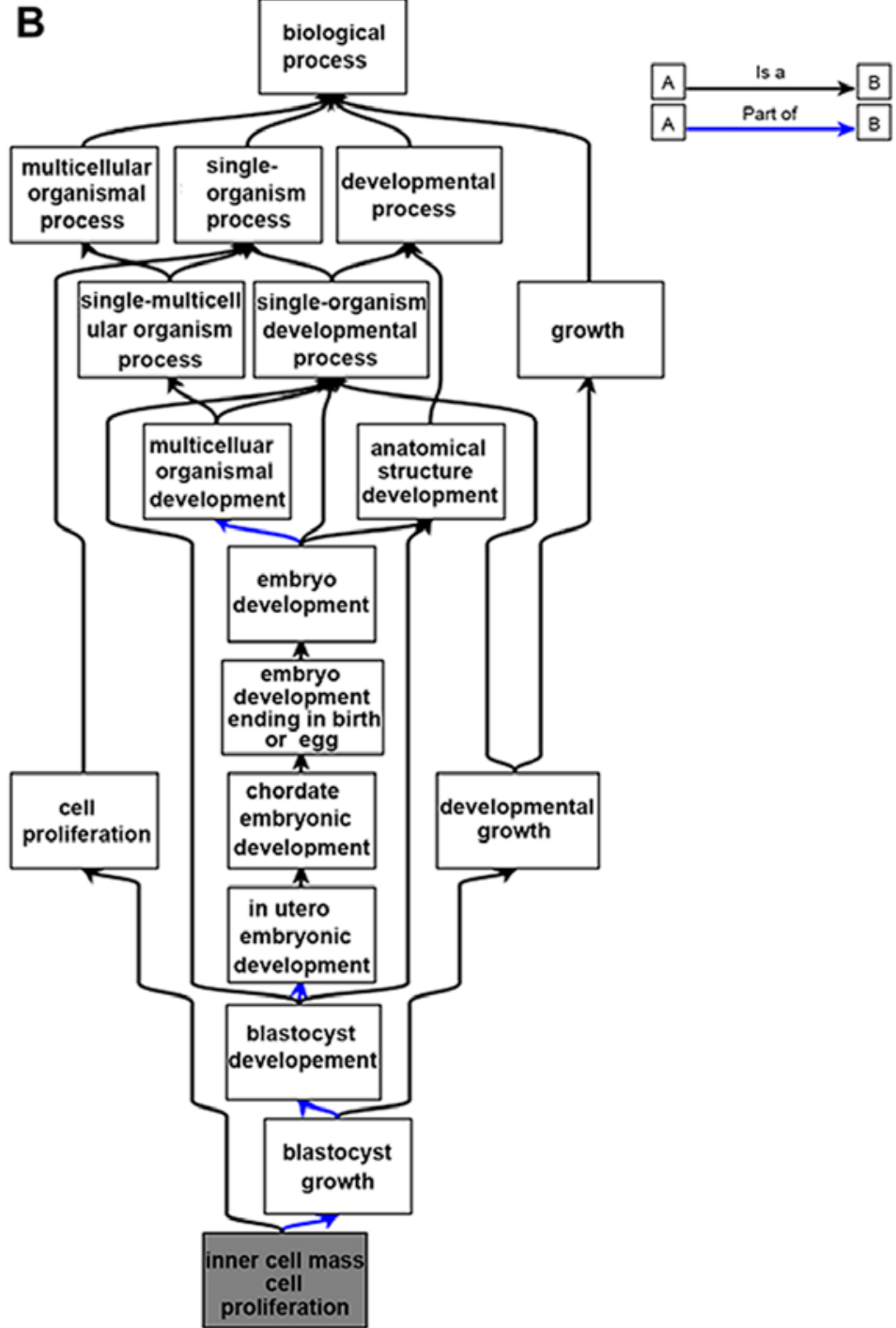

Figure 5. Biological process of SETDB1. (A) Bone development, progression of bone over time, from its formation to the mature structure. (B) Inner cell mass cell proliferation, the proliferation of cells in the inner cell mass.

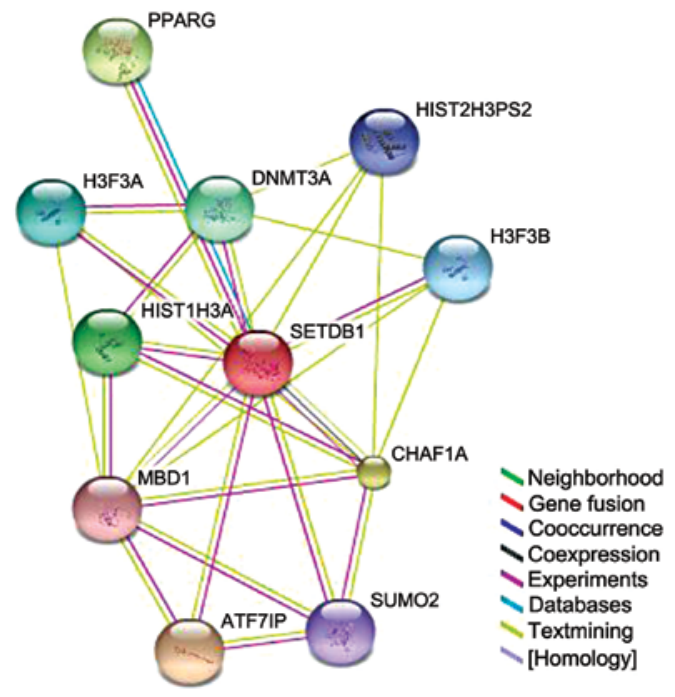

Figure 6. The SETDB1 single protein function partner network was indicated by String analysis. SETDB1 interacts with MBD1, PPARG, ATF7IP, H3F3B and H3F3A. Different line colors represent the types of evidencefor the association.

\section{Discussion}

Proteomics is a powerful approach for the identification of novel cancer biomarkers or key proteins $(15,16)$. However, little is known about how tumor cells acquire the ability to spread to initiate metastases because of the complexity of the process. The present study aimed to identify proteins differentially expressed between normal prostate cells and two PCa cell lines with different metastatic potential by coupling LCM with 2D-DIGE. LCM is one of the best technologies for obtaining specific tissues (17-19). Eighty-six proteins were significantly different between the cell lines. Among them, twelve proteins were identified successfully by MALDI-TOF-MS. One protein was upregulated in normal prostate epithelial cells, nine proteins were upregulated in PC-3, and two proteins were upregulated in PC-3M. The SETDB1 protein was closely associated with the prognosis of PCa. Bioinformatics suggested that SETDB1 likely promotes PCa bone metastases through the WNT pathway.

Previously, traditional 2-DE proteomic studies of PCa identified a large number of differentially expressed proteins and 
some were reported as potential markers for diagnosis of localized PCa (20-23). Some studies of 2D-DIGE-based proteomics focused to identify novel clinically relevant proteins in $\mathrm{PCa}$ (24-26). In the present study, compared with normal prostate epithelial cells, eleven differentially expressed proteins were identified as potential candidates associated with prostate cancer metastases. Of them, some were demonstrated to be related to $\mathrm{PCa}$ and other cancers in previous studies including ATP synthase subunit $\beta$ (27,28), heat shock protein (HSP) (29), stress-70 protein (30), keratin type I cytoskeletal 19 (31-34), keratin type I cytoskeletal $18(35,36)$, and TUBA1C (37). These results indicated that our proteomic strategy was an effective approach to identify key proteins closely associated with prostate cancer.

In the present study, SETDB1 was significantly elevated in human PCa PC-3 cells. SETDB1 is a member of the histonelysine methyltransferase family, Suvar 3-9 subfamily. The SETDB1 protein is 1291-amino acid long, and is located in the nucleus and chromosomes. Members of this subfamily trimethylate Lys-9 of histone H3. H3 Lys-9 trimethylation represents a specific tag for epigenetic transcriptional repression by recruiting HP1 (CBX1, CBX3 and/or CBX5) proteins to methylated histones (38). This enzyme mainly functions in euchromatin regions, playing a central role in the silencing of euchromatic genes. H3 Lys-9 trimethylation is coordinated with DNA methylation. It probably forms a complex with MBD1 and ATF7IP that represses transcription and couples DNA methylation and histone Lys-9 trimethylation (39). Its activity is dependent on MBD1 and is heritably maintained through DNA replication by being recruited by CAF-1 (40). SETDB1 is targeted to histone $\mathrm{H} 3$ by TRIM28/TIF1B, a factor recruited by KRAB zinc-finger proteins (41).

SETDB1 is highly upregulated in patients with Huntington's disease, suggesting that it participates in the altered chromatin modulation and transcription dysfunction observed in Huntington's disease (42). SETDB1 has been established as an oncogene in a number of human carcinomas. A study has demonstrated the role of histone lysine methyltransferases SUV39H1 and SETDB1 in gliomagenesis and its association with cell proliferation, migration, and colony formation (43). Another study found that SETDB1 positively stimulated the $\mathrm{WNT} / \beta$-catenin pathway and decreased P53 expression, resulting in enhanced non-small cell lung cancer growth in vitro and in vivo (44). Some authors have shown that miR-7, which is downregulated in the breast cancer MCF-7 and MDA-MB-231 cell lines, inhibited cell invasion and metastasis, decreased the breast cancer stem cell population, and partially reversed the epithelial-mesenchymal transition in MDA-MB-231 cells by directly targeting SETDB1 (45). In addition, SETDB1 is a candidate gene for melanoma susceptibility (46).

Recently, a study examined the function of SETDB1 in PCa (47), and has shown that silencing SETDB1 in 22RV-1 PCa cells inhibited PCa cell proliferation, migration, and invasion. However, the SETDB1 pathway is not clear, and its involvement in PCa metastases is even less clear. Using bioinformatics, it is known that SETDB1 participates in the process of bone development and inner cell mass proliferation. The data from the GeneCards database show that the SETDB1 protein is involved in three classical pathways: chromatin regulation/acetylation, non-canonical Wnt signaling, and lysine degradation. A number of studies suggest that SETDB1 promotes tumorigenesis and metastasis through the $\mathrm{WNT} / \beta$ catenin pathway $(44,47)$. However, further studies are required to assess this point.

The present study is not without its limitations. Results were obtained by bioinformatics and need to be confirmed in cell and animal models. The results of the present study were mostly obtained from cell lines, and should be confirmed in a complete set of actual PCa obtained from patients.

In conclusion, SETDB1 might be associated with the development of bone metastases from PCa. Further study is necessary to assess its exact role in $\mathrm{PCa}$ and its involvement in the WNT pathway.

\section{Acknowledgements}

This study was supported by the Science and Technology Development Foundation from Pudong New District, Shanghai, China (PKJ2012-Y11), the Natural Science Foundation of Shanghai (14ZR1433900), the Outstanding Young Foundation from Pudong New District, Shanghai, China (PWRq2011-16), the Shanghai medical key specialty (ZK2012A26), Key Disciplines Group Construction Project of Pudong Health Bureau of Shanghai (PWZxq2014-04) and National Natural Science Foundation of China (81502288).

\section{References}

1. Center MM, Jemal A, Lortet-Tieulent J, Ward E, Ferlay J, Brawley $\mathrm{O}$ and Bray $\mathrm{F}$ : International variation in prostate cancer incidence and mortality rates. Eur Urol 61: 1079-1092, 2012.

2. Ian LH, Li H, Yang Y and Ho CF: Comparisons of the incidence and pathological characteristics of prostate cancer between Chinese and Portuguese in Macau. Chin Med J (Engl) 121: 292-294, 2008.

3. Greene KL, Albertsen PC, Babaian RJ, Carter HB, Gann PH, Han M, Kuban DA, Sartor AO, Stanford JL, Zietman A, et al: Prostate specific antigen best practice statement: 2009 update. J Urol 182: 2232-2241, 2009.

4. Schröder FH, Hugosson J, Roobol MJ, Tammela TL, Ciatto S, Nelen V, Kwiatkowski M, Lujan M, Lilja H, Zappa M, et al; ERSPC Investigators: Screening and prostate-cancer mortality in a randomized European study. N Engl J Med 360: 1320-1328, 2009.

5. Abdollah F, Sun M, Thuret R, Budäus L, Jeldres C, Graefen M, Briganti A, Perrotte P, Rigatti P, Montorsi F, et al: Decreasing rate and extent of lymph node staging in patients undergoing radical prostatectomy may undermine the rate of diagnosis of lymph node metastases in prostate cancer. Eur Urol 58: 882-892, 2010.

6. Budäus L, Isbarn H, Eichelberg C, Lughezzani G, Sun M, Perrotte P, Chun FK, Salomon G, Steuber T, Köllermann J, et al: Biochemical recurrence after radical prostatectomy: Multiplicative interaction between surgical margin status and pathological stage. J Urol 184: 1341-1346, 2010.

7. $\mathrm{Wu} \mathrm{CC}$ and MacCoss MJ: Shotgun proteomics: Tools for the analysis of complex biological systems. Curr Opin Mol Ther 4: 242-250, 2002.

8. Arya M, Patel HR, McGurk C, Tatoud R, Klocker H, Masters J and Williamson M: The importance of the CXCL12-CXCR4 chemokine ligand-receptor interaction in prostate cancer metastasis. J Exp Ther Oncol 4: 291-303, 2004.

9. Orenes-Piñero E, Cortón M, González-Peramato P, Algaba F, Casal I, Serrano A and Sánchez-Carbayo M: Searching urinary tumor markers for bladder cancer using a two-dimensional differential gel electrophoresis (2D-DIGE) approach. J Proteome Res 6: 4440-4448, 2007.

10. Klopfleisch R, Klose P, Weise C, Bondzio A, Multhaup G, Einspanier R and Gruber AD: Proteome of metastatic canine mammary carcinomas: Similarities to and differences from human breast cancer. J Proteome Res 9: 6380-6391, 2010. 
11. Ummanni R, Junker H, Zimmermann U, Venz S, Teller S, Giebel J, Scharf C, Woenckhaus C, Dombrowski F and Walther R: Prohibitin identified by proteomic analysis of prostate biopsies distinguishes hyperplasia and cancer. Cancer Lett 266: 171-185, 2008 .

12. Lexander H, Hellman U, Palmberg C, Auer G, Hellström M, Franzén B, Jörnvall H and Egevad L: Evaluation of two sample preparation methods for prostate proteome analysis. Proteomics 6: 3918-3925, 2006

13. Zhang W and Chait BT: ProFound: An expert system for protein identification using mass spectrometric peptide mapping information. Anal Chem 72: 2482-2489, 2000.

14. Jensen LJ, Kuhn M, Stark M, Chaffron S, Creevey C, Muller J, Doerks T, Julien P, Roth A, Simonovic M, et al: STRING 8 - a global view on proteins and their functional interactions in 630 organisms. Nucleic Acids Res 37 (Database): D412-D416, 2009.

15. Cho S, Choi YS, Yim SY, Yang HI, Jeon YE, Lee KE, Kim H, Seo SK and Lee BS: Urinary vitamin D-binding protein is elevated in patients with endometriosis. Hum Reprod 27: 515-522, 2012.

16. Hanley JA and McNeil BJ: The meaning and use of the area under a receiver operating characteristic (ROC) curve. Radiology 143: 29-36, 1982.

17. Li C, Hong Y, Tan YX, Zhou H, Ai JH, Li SJ, Zhang L, Xia QC, Wu JR, Wang HY, et al: Accurate qualitative and quantitative proteomic analysis of clinical hepatocellular carcinoma using laser capture microdissection coupled with isotope-codec affinity tag and two-dimensional liquid chromatography mass spectrometry. Mol Cell Proteomics 3: 399-409, 2004

18. Neubauer H, Clare SE, Kurek R, Fehm T, Wallwiener D, Sotlar K, Nordheim A, Wozny W, Schwall GP, Poznanović S, et al: Breast cancer proteomics by laser capture microdissection, sample pooling, 54-cm IPG IEF, and differential iodine radioisotope detection. Electrophoresis 27: 1840-1852, 2006.

19. Patel V, Hood BL, Molinolo AA, Lee NH, Conrads TP, Braisted JC, Krizman DB, Veenstra TD and Gutkind JS Proteomic analysis of laser-captured paraffin-embedded tissues: A molecular portrait of head and neck cancer progression. Clin Cancer Res 14: 1002-1014, 2008

20. Hessels D, Verhaegh GW, Schalken JA and Witjes JA Applicability of biomarkers in the early diagnosis of prostate cancer. Expert Rev Mol Diagn 4: 513-526, 2004.

21. Kumar-Sinha C, Rhodes DR, Yu J and Chinnaiyan AM: Prostate cancer biomarkers: A current perspective. Expert Rev Mol Diagn 3: 459-470, 2003.

22. Rubin MA, Zhou M, Dhanasekaran SM, Varambally S Barrette TR, Sanda MG, Pienta KJ, Ghosh D and Chinnaiyan AM: alpha-Methylacyl coenzyme A racemase as a tissue biomarker for prostate cancer. JAMA 287: 1662-1670, 2002.

23. Solassol J, Marin P, Demettre E, Rouanet P, Bockaert J, Maudelonde T and Mangé A: Proteomic detection of prostatespecific antigen using a serum fractionation procedure: Potential implication for new low-abundance cancer biomarkers detection Anal Biochem 338: 26-31, 2005

24. Byrne JC, Downes MR, O'Donoghue N, O'Keane C, O'Neill A, Fan Y, Fitzpatrick JM, Dunn M and Watson RW: 2D-DIGE as a strategy to identify serum markers for the progression of prostate cancer. J Proteome Res 8: 942-957, 2009.

25. Ummanni R, Barreto F, Venz S, Scharf C, Barett $C$, Mannsperger HA, Brase JC, Kuner R, Schlomm T, Sauter G et al: Peroxiredoxins 3 and 4 are overexpressed in prostate cancer tissue and affect the proliferation of prostate cancer cells in vitro. J Proteome Res 11: 2452-2466, 2012.

26. Han ZD, Zhang YQ, He HC, Dai QS, Qin GQ, Chen JH, Cai C, $\mathrm{Fu} \mathrm{X}, \mathrm{Bi} \mathrm{XC}, \mathrm{Zhu} \mathrm{JG}$, et al: Identification of novel serological tumor markers for human prostate cancer using integrative transcriptome and proteome analysis. Med Oncol 29: 2877-2888, 2012.

27. Liu X,Wu Y,ZehnerZE, Jackson-Cook C and Ware JL: Proteomic analysis of the tumorigenic human prostate cell line M12 after microcell-mediated transfer of chromosome 19 demonstrates reduction of vimentin. Electrophoresis 24: 3445-3453, 2003.

28. Isidoro A, Martínez M, Fernández PL, Ortega AD, Santamaría G, Chamorro M, Reed JC and Cuezva JM: Alteration of the bioenergetic phenotype of mitochondria is a hallmark of breast, gastric, lung and oesophageal cancer. Biochem J 378: 17-20, 2004.
29. Rylander MN, Feng Y, Zimmermann K and Diller KR: Measurement and mathematical modeling of thermally induced injury and heat shock protein expression kinetics in normal and cancerous prostate cells. Int J Hyperther 26: 748-764, 2010.

30. Zvereff V, Wang JC, Shun K, Lacoste J and Chevrette M: Colocalisation of CD9 and mortalin in CD9-induced mitotic catastrophe in human prostate cancer cells. Br J Cancer 97: 941-948, 2007.

31. Tobias-Machado M, Fonseca F, Fantinato AP, Bendit I, Wroclawski ML, Wroclawski E and del Giglio A: Cytokeratin 19 expression by reverse transcriptase-polymerase chain reaction in the peripheral blood of prostate cancer patients. Tumori 91: 248-252, 2005.

32. Peehl DM, Sellers RG and McNeal JE: Keratin 19 in the adult human prostate: Tissue and cell culture studies. Cell Tissue Res 285: 171-176, 1996

33. Kaneda T, Hoshi S, Mao H, Takahashi T, Suzuki K, Sato M and Orikasa S: Detection of urogenital malignant cells in the peripheral blood by nested RT-PCR using keratin 19 mRNA. Nippon Hinyokika Gakkai Zasshi 89: 33-42, 1998 (In Japanese).

34. Senga Y, Kimura G, Hattori T and Yoshida K: Clinical evaluation of soluble cytokeratin 19 fragments (CYFRA 21-1) in serum and urine of patients with bladder cancer. Urology 48: 703-710, 1996.

35. Wolff JM, Borchers H, Brehmer B Jr, Brauers A and Jakse G: Cytokeratin 8/18 levels in patients with prostate cancer and benign prostatic hyperplasia. Urol Int 60: 152-155, 1998

36. Cecena G, Wen F, Cardiff RD and Oshima RG: Differential sensitivity of mouse epithelial tissues to the polyomavirus middle T oncogene. Am J Pathol 168: 310-320, 2006

37. Li Y, Liang Q, Wen YQ, Chen LL, Wang LT, Liu YL, Luo CQ, Liang HZ, Li MT and Li Z: Comparative proteomics analysis of human osteosarcomas and benign tumor of bone. Cancer Genet Cytogenet 198: 97-106, 2010

38. Ayyanathan K, Lechner MS, Bell P, Maul GG, Schultz DC, Yamada Y, Tanaka K, Torigoe K and Rauscher FJ III: Regulated recruitment of HP1 to a euchromatic gene induces mitotically heritable, epigenetic gene silencing: A mammalian cell culture model of gene variegation. Genes Dev 17: 1855-1869, 2003.

39. Wang H, An W, Cao R, Xia L, Erdjument-Bromage H, Chatton B, Tempst P, Roeder RG and Zhang Y: mAM facilitates conversion by ESET of dimethyl to trimethyl lysine 9 of histone $\mathrm{H} 3$ to cause transcriptional repression. Mol Cell 12: 475-487, 2003.

40. Sarraf SA and Stancheva I: Methyl-CpG binding protein MBD1 couples histone $\mathrm{H} 3$ methylation at lysine 9 by SETDB1 to DNA replication and chromatin assembly. Mol Cell 15: 595-605, 2004.

41. Takada I, Mihara M, Suzawa M, Ohtake F, Kobayashi S, Igarashi M, Youn MY, Takeyama K, Nakamura T, Mezaki Y, et al: A histone lysine methyltransferase activated by non-canonical Wnt signalling suppresses PPAR-gamma transactivation. Nat Cell Biol 9: 1273-1285, 2007.

42. Ryu H, Lee J, Hagerty SW, Soh BY, McAlpin SE, Cormier KA, Smith KM and Ferrante RJ: ESET/SETDB1 gene expression and histone H3 (K9) trimethylation in Huntington's disease. Proc Natl Acad Sci USA 103: 19176-19181, 2006.

43. Spyropoulou A, Gargalionis A, Dalagiorgou G, Adamopoulos C, Papavassiliou KA, Lea RW, Piperi C and Papavassiliou AG: Role of histone lysine methyltransferases SUV39H1 and SETDB1 in gliomagenesis: Modulation of cell proliferation, migration, and colony formation. Neuromol Med 16: 70-82, 2014

44. Sun Q, Ding L, Xiao J, Chien W, Lim S, Hattori N, Goodglick L, Chia D, Mah V, Alavi M, et al: SETDB1 accelerates tumourigenesis by regulating the WNT signalling pathway. J Pathol 235: $559-570,2015$

45. Zhang H, Cai K, Wang J, Wang X, Cheng K, Shi F, Jiang L, Zhang Y and Dou J: MiR-7, inhibited indirectly by lincRNA HOTAIR, directly inhibits SETDB1 and reverses the EMT of breast cancer stem cells by downregulating the STAT3 pathway. Stem Cells 32: 2858-2868, 2014.

46. Macgregor S, Montgomery GW, Liu JZ, Zhao ZZ, Henders AK, Stark M, Schmid H, Holland EA, Duffy DL, Zhang M, et al: Genome-wide association study identifies a new melanoma susceptibility locus at 1q21.3. Nat Genet 43: 1114-1118, 2011.

47. Sun Y, Wei M, Ren SC, Chen R, Xu WD, Wang FB, Lu J, Shen J, $\mathrm{Yu}$ YW, Hou JG, et al: Histone methyltransferase SETDB1 is required for prostate cancer cell proliferation, migration and invasion. Asian J Androl 16: 319-324, 2014. 